\title{
Editorial
}

\section{Revisiting the One Health Approach in the Context of COVID-19: A Look into the Ecology of this Emerging Disease}

\author{
D. Katterine Bonilla-Aldana ${ }^{1,2}$, Kuldeep Dhama ${ }^{3}$, Alfonso J. Rodriguez-Morales ${ }^{2,4^{*}}$
}

${ }^{1}$ Incubator in Zoonosis (SIZOO), Biodiversity and Ecosystem Conservation Research Group (BIOECOS), Fundación Universitaria Autónoma de las Américas, Sede Pereira, Pereira, Risaralda, Colombia.; ${ }^{2}$ Public Health and Infection Research Group, Faculty of Health Sciences, Universidad Tecnológica de Pereira, Pereira, Risaralda, Colombia; ${ }^{3}$ Division of Pathology, ICAR-Indian Veterinary Research Institute, Izatnagar 243 122, Bareilly, Uttar Pradesh, India; ${ }^{4}$ Grupo de Investigación Biomedicina, Faculty of Medicine, Fundación Universitaria Autónoma de las Américas, Pereira, Risaralda, Colombia.

\author{
Received | March 01, 2020; Accepted | March 06, 2020; Published | March 06,2020 \\ *Correspondence | Alfonso J. Rodriguez-Morales, Public Health and Infection Research Group, Faculty of Health Sciences, Universidad Tecnológica de Pereira, \\ Pereira, Risaralda, Colombia; Email: ajrodriguezmmd@gmail.com \\ Citation | Bonilla-Aldana DK, Dhama K, Rodriguez-Morales AJ (2020). Revisiting the One Health Approach in the Context of COVID-19: A look into the \\ Ecology of this Emerging Disease. Adv. Anim. Vet. Sci. 8(3): 234-237. \\ DOI | http://dx.doi.org/10.17582/journal.aavs/2020/8.3.234.237 \\ ISSN (Online) | 2307-8316; ISSN (Print) | 2309-3331 \\ Keywords | One Health; Zoonoses; Coronavirus; COVID-19; SARS-CoV-2.
}

Copyright (C) 2020 Rodriguez-Morales et al. This is an open access article distributed under the Creative Commons Attribution License, which permits unrestricted use, distribution, and reproduction in any medium, provided the original work is properly cited.

$\mathrm{T}$ The "One Health" concept was introduced at the beginning of the 2000s. In a few words, it summarized an idea that had been known for more than a century; that human health and animal health are interdependent and bound to the health of the ecosystems in which they exist (OIE, 2020). This concept is envisaged and implemented by the World Organization for Animal Health (OIE), but also for multiple other organizations, as a collaborative global approach to understanding risks for human and animal health, including both domestic animals and wildlife, and ecosystem health as a whole (OIE, 2020).

One Health is an approach that recognizes that human health is closely related to animal health and environmental health. In a broad sense, the integrated health results from the interaction between humans, animals, and the environment, including other living beings, such as the plants. This initiative is of great importance to the extent that we can discuss it in the context of infectious disease ecology, where both animals and the environment have significant relationships and relevance for the occurrence of emerging zoonotic diseases in animals and humans (Dhama et al., 2013; Bonilla-Aldana et al., 2019). Furthermore, thorough knowledge of the relationships between host, pathogen and environment along with their ecology is crucial to counter infectious pathogens.

Zoonotic diseases, in general, are good examples of this. The threat of emerging and re-emerging zoonoses has now increased globally due to several factors such as bloom in trade and travel, climate change, rapidly evolving pathogens, population explosion, changing habbits and lifestyle of humans, intensive integrated animal farming, and others. Within the group of zoonotic diseases, there is a wide range of infectious diseases caused by viral, bacterial, parasitic, fungal, and even prion pathogens. In this context, we must say that emerging diseases are particularly associated with environmental and animal factors. Exogenous zoonotic pathogens commonly undergo mutations and after jumping species barrier opt for adaptation to the hostile environmental conditions before spillover to humans (Ellwanger and Chies, 2018). The interaction between these components is critical in the understating of what happened in the case of the Severe Acute Respiratory Syndrome (SARS), the Middle East Respiratory Syndrome (MERS) and now the Coronavirus Diseases 2019 (COVID-19), bcaused by the SARS-2 Coronavirus (SARS-CoV-2) (Dhama et al., 2020; Rodriguez-Morales, Bonilla-Aldana, et al., 2020) (Figure 1). 


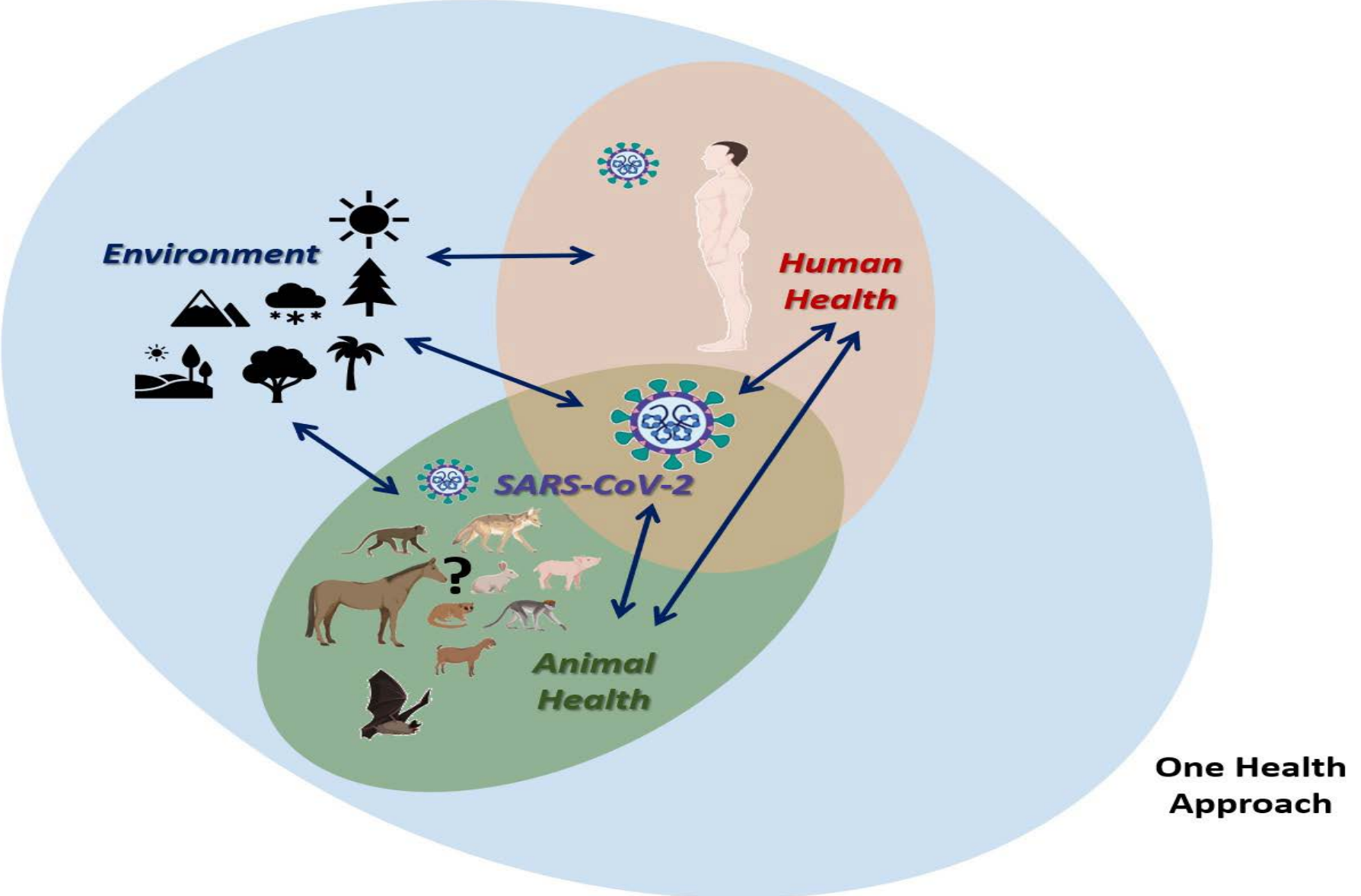

Figure 1: One health approach in the context of coronavirus disease 2019 (COVID-19) caused by the SARS-CoV-2.

Over the past two decades we have seen the destructive capacity of coronaviruses that are constantly evolving, resulting in fatal outbreaks that pose a significant threat to global public health. The noval coronavirus that has recently emerged is considered as the third $\mathrm{CoV}$ outbreak in humans (Munster et al., 2020). The COVID-19, emerged in Wuhan, China (Li et al., 2020; Liu \& Saif, 2020), at the end of 2019, causing respiratory, digestive, and systematic manifestations that adversely affect the human health. This RNA virus can be transmitted from person to person through airborne particles and drops, infecting type 2 pneumocytes and ciliated bronchial epithelial cells using ACE2 receptors (Lu et al., 2020; Rodriguez-Morales, MacGregor, Kanagarajah, Patel, \& Schlagenhauf, 2020). The initial analysis of primary cases suggests a common exposure point for all of the infected individuals, the seafood market in Wuhan, Hubei Province, China. The restaurants of this market are quite famous for serving several types of wildlife for human consumption (Hui et al., 2020). The Huanan South China Seafood Market is an example for a wet-market that sells poultry, bats, snakes, marmots and other wild animals. Such wet-markets are hotspots that act as a human-animal interphase, an ideal point where novel zoonotic viruses can jump the species barrier resulting in the emergence of novel pathogens. It is also related to other coronaviruses that circulate among bats, including
SARS-CoV, so it is argued that such animals are the possible natural host, but other mammals should be involved as intermediate hosts (Malik et al., 2020). Hence the circumstantial evidence available from the seafood market in Wuhan points out the possibility of an intermediate host in COVID-19 outbreak that transmitted the novel virus to humans similar to their predecessors SARS and MERS. In this way, it is imperative to understand the conditions in which the transmission occurs, where the transmission is associated in the first instance in an environment in which there are favorable conditions for the existence and interaction of natural host animals or reservoirs that may be able to carry the SARS-CoV-2 under appropriate circumstances and that in the interaction with the human being the possibility of establishing transmission is completed (Figure 1). This should lead to the discussion on the integrative approach and studies of diseases in the environment, disease ecology (Caron et al., 2015), that goes beyond the clinical and pathological findings in human beings and occurrence in animals. In the case of COVID-19, as occurs for other emerging zoonotic diseases, it is essential to begun studies assessing which were the environmental conditions in Wuhan where the first cases presented, but in general in places where studies of animal reservoirs of SARS-CoV-2 will take place, including temperature, rainfall, humidity, vegetations, as other factors 
relevant for the animal distribution, and also interactions with human beings (Figure 1). COVID-19 outbreak is the third instance where the virus has crossed the so called species barrier twice from wild animals to human beings after the occurrence of SARS, and MERS outbreaks. The possibility of a fourth outbreak can be expected in the coming future, possibly at a huma-animal interphase just like the wet-market in Wuhan.

It is crucial from the One Health perspective not only to understand the transmission cycles but also to look for mechanisms of prevention and mitigation of transmission that may be useful for future risk conditions in the context of emerging zoonotic diseases including coronavirus as the case of COVID-19 (Ahmad et al., 2020). Strategic breach in the interaction between host, pathogen and their environment may provide an efficient control over many probable zoonoses in future. Furthermore, strong intersectoral collaboration and coordination between the animal and human health sectors at regional, national and international levels is an utmost necessasity to prevent, control and eliminate emerging zoonoses. Urgent and strategic adoption of One health approach along with an integrated surveillance, monitoring and networking system, appropriately supported by rapid and confirmatory laboratory investigation facilities, effective immunization/vaccination and therapeutic approaches along with adopting appropriate prevention and control measures are altogether highly anticipated to curb the emerging zoonoses globally (Dhama et al., 2013; Awaidy et al., 2020). Besides these, due attention towards public awareness and collaborative disease control strategies need to be implemented in the right directons amomg different sectors and stake-holders (medical, veterinary, government departments, non-government organizations, NGOs) and various regulatory health agencies for implementing warranted interventions for effectively checking the transmisión and spread, and control of the emerging, re-emerging and zoonotic threats posed by infectious pathogens.

COVID-19 has presently spread to more than 82 countries, apart from China from where it originated. As per the most recent situation report of World Health Organization (WHO), a total of 94,355 confirmed cases and 3,222 humans deaths have been reported till March 4, 2020 (WHO, 2020). This virus was designated as a Public Health International Emergency on January 30, 2020 and a potential pandemic. Seeing the rapid increase in the number of cases affected and its further spread to many countries in all the populated regions of the world, except Antarctica. WHO has now increased the risk assessment of this emerging coronavirus to a very high risk category. Researchers and health agencies accross the globe are putting their high efforts to hault the spread of this virus by adopting appropriate prevention and control measures, and are pacing high to develop effective vaccines and therapeutics to avoid any pandemic situation. In this direction, One health approach is also critical for countering COVID-19 and other emerging coronaviral and viral zoonotic diseases.

\section{REFERENCES}

-Ahmad T, Khan M, Haroon Musa TH, Nasir S, Hui J, Rodriguez-Morales AJ (2020). COVID-19: Zoonotic aspects. Travel Med. Infect. Dis. 101607. https://doi.org/10.1016/j.tmaid.2020.101607

-Awaidy SA, Al Hashami H (2020). Zoonotic Diseases in Oman: Successes, Challenges, and Future Directions. Vector Borne Zoonot. Dis. 20(1): 1-9. https://doi.org/10.1089/vbz.2019.2458.

-Bonilla-Aldana DK, Suarez JA, Franco-Paredes C, Vilcarromero S, Mattar S, Gomez-Marin JE, Rodriguez-Morales AJ (2019). Brazil burning! What is the potential impact of the Amazon wildfires on vector-borne and zoonotic emerging diseases? - A statement from an international experts meeting. Travel Med. Infect. Dis. 31/ 101474. https://doi. org/10.1016/j.tmaid.2019.101474

-Caron A, Cappelle J, Cumming GS, de GarineWichatitsky M, Gaidet N (2015). Bridge hosts, a missing link for disease ecology in multi-host systems. Vet. Res. 46. 83. https://doi.org/10.1186/ s13567-015-0217-9

-Dhama K, Chakraborty S, Kapoor S, Tiwari R, Kumar A, Deb R, Rajagunalan S, Singh R., Vora, $\mathrm{K}$ and Natesan, S. (2013). One world, one health veterinary perspectives. Adv. Anim. Vet. Sci. 1(1): 5-13.

-Dhama K, Sharun K, Tiwari R, Sircar S, Bhat S, Malik YS, Singh KP, Chaicumpa W, Bonilla-Aldana DK, Rodriguez-Morales AJ (2020). Coronavirus disease 2019 - COVID-19. Preprints. 2020030001. https:// doi.org/10.20944/preprints202003.0001.v1

-Ellwanger JH, Chies JAB (2018). Zoonotic spillover and emerging viral diseases - time to intensify zoonoses surveillance in Brazil. Braz. J. Infect. Dis. 22(1): 7678. https://doi.org/10.1016/j.bjid.2017.11.003.

- Hui DS, I Azhar E, Madani TA, Ntoumi F, Kock R, Dar O, Ippolito G, Mchugh TD, Memish ZA, Drosten C, Zumla A, Petersen E. 2020. The continuing 2019-nCoV epidemic threat of novel coronaviruses to global health - The latest 2019 novel coronavirus outbreak in Wuhan, China. Int. J. Infect. Dis. 91:264-266. https://doi.org/10.1016/j. ijid.2020.01.009.

-Li Q, Guan X, Wu P, Wang X, Zhou L, Tong Y, Feng $Z$ (2020). Early Transmission Dynamics in Wuhan, China, of Novel Coronavirus-Infected Pneumonia. N. Engl. J. Med. https://doi.org/10.1056/ 


\section{NEJMoa2001316}

-Liu SL, Saif L (2020). Emerging Viruses without Borders: The Wuhan Coronavirus. Viruses. 12(2). https://doi.org/10.3390/v12020130

- Lu R, Zhao X, Li J, Niu P, Yang B, Wu H, Tan W (2020). Genomic characterisation and epidemiology of 2019 novel coronavirus: implications for virus origins and receptor binding. Lancet. 395(10224): 565-574. https://doi.org/10.1016/S0140-6736(20)30251-8

-Malik YS, Sircar S, Bhat S, Sharun K, Dhama K, Dadar M, Tiwari R, Chaicumpa W (2020). Emerging novel Coronavirus (2019-nCoV)-Current scenario, evolutionary perspective based on genome analysis and recent developments. Vet. Q. 40:68-76. https:// doi.org/10.1080/01652176.2020.172799.

- Munster VJ, Koopmans M, van Doremalen N, van Riel $\mathrm{D}$, de Wit E (2020). A novel Coronavirus emerging in China-key questions for impact assessment. N.
Engl. J. Med. 10.1056/NEJMp2000929. https:// doi.org/10.1056/NEJMp2000929

-OIE (2020). One Health. https://www.oie.int/en/forthe-media/onehealth/.

-Rodriguez-Morales AJ, Bonilla-Aldana DK, BalbinRamon GJ, Paniz-Mondolfi A, Rabaan A, Sah R, Esposito S (2020). History is repeating itself, a probable zoonotic spillover as a cause of an epidemic: the case of 2019 novel Coronavirus. Infez. Med. 28(1): 3-5.

-Rodriguez-Morales AJ, MacGregor K, Kanagarajah S, Patel D, Schlagenhauf P (2020). Going global Travel and the 2019 novel coronavirus. Travel Med. Infect. Dis. 33: 101578. https://doi.org/10.1016/j. tmaid.2020.101578

-WHO (2020). https://www.who.int/docs/defaultsource/coronaviruse/situation-reports/20200303sitrep-43-covid-19.pdf?sfvrsn=2c21c09c_2 